\title{
PENGGUNAAN APLIKASI I-SAFE DALAM PENERAPAN KESELAMATAN PERTAMBANGAN PT. BORNEO INDOBARA KALIMANTAN SELATAN
}

\author{
Bakhtiar Rusandi Sinaga $^{1)}$, Kinanto Prabu Werdana ${ }^{2)}$, Dicky Irwanto ${ }^{3)}$, Noor Hanafi ${ }^{4)}$ \\ ${ }^{1)}$ Section Head HSE Pit Operation, PT. Borneo Indobara \\ ${ }^{2)}$ Team Leader Environmental, PT. Borneo Indobara \\ ${ }^{3)}$ Team Leader HSE System, PT. Borneo Indobara \\ ${ }^{4)}$ Team Leader HSE Project, PT. Borneo Indobara
}

\begin{abstract}
ABSTRAK
Salah satu penyebab kecelakaan pertambangan adalah kondisi tidak aman dan tindakan tidak aman dari pekerja pekerja tambang. cara efektif dalam mengelola bahaya tersebut adalah dengan melaporkan bahaya tersebut. Saat ini pelaporan bahaya tersebut diwajibkan kepada seluruh pengawas operasional, sayangnya hasil dari aktifitas tersebut belum terdokumentasi dengan baik karena proses masukan masih dilakukan secara manual sehingga perlu waktu yang tidak sedikit dan hasilnya belum efektif untuk memberikan rekomendasi perbaikan terhadap bahaya tersebut. Selain itu media untuk melakukan kegiatan tersebut menggunakan kertas, terkadang pengawas operasional kesulitan mendapatkan form ketika berada di lapangan sehingga menyulitkan pembuktian dokumentasi dalam menemukan kondisi tidak aman dan tindakan tidak aman. Berdasarkan permasalahan tersebut maka dibuat system dan aplikasi dalam memudahkan proses dokumentasi dalam bentuk aplikasi mobile yang dapat di akses dalam kondisi offline/online,dimanapun, kapanpun melalui mobile phone dan database yang direkam dapat digunakan sebagai acuan dalam analisa dan evaluasi data untuk pengendalian pencegahan kecelakaan. Analisa dari aplikasi tersebut terbukti meningkatkan jumlah pelaporan kondisi tidak aman dan tindakan tidak aman hingga $15 \%$ dari pelaporan menggunakan formulir. berdasarkan pelaporan bahaya tersebut, kita dapat mengetahui tempat-tempat kritis yang sering ditemukan adanya penyimpangan sehingga pada area tersebut lebih prioritas dalam pengendalian bahaya dan resiko yang timbul. Lebih dari itu aplikasi ini juga linier dengan misi perusahaan dalam pengelolaan lingkungan karena pengurangan pemakaian kertas menjadi digital. Berdasarkan hasil kajian diatas implementasi aplikasi I-Safe dapat meningkatkan kepedulian pekerja tambang mengenai keselamatan kerja dan database yang direkam dapat digunakan sebagai dasar pengambilan keputusan yang valid. Hal ini sejalan sebagai salah satu bentuk penerapan pengelolaan keselamatan pertambangan Indonesia dalam menghadapi era industri 4.0 mengenai digitalisasi, keselamatan dan pertambangan.
\end{abstract}

Kata Kunci : aplikasi, I-Safe, database, evaluasi, keselamatan

\begin{abstract}
One of the causes of mining accidents is unsafe conditions and unsafe actions from mining workers. an effective way to manage the hazard is to report the hazard. Currently the hazard reporting is required for all operational supervisors, unfortunately the results of these activities have not been well documented because the input process is still done manually so that it takes a lot of time and the results have not been effective to provide recommendations for improvement of the hazard. In addition to the media to carry out these activities using paper, sometimes operational supervisors have difficulty getting forms while in the field, making it difficult to prove documentation in finding unsafe conditions and unsafe actions. Based on these problems, systems and applications are made to facilitate the process of documentation in the form of mobile applications that can be accessed in an offline / online condition, anywhere, anytime through a
\end{abstract}


mobile phone and a recorded database can be used as a reference in the analysis and evaluation of data for accident prevention control. Analysis of the application has been proven to increase the number of reporting unsafe conditions and unsafe actions to $15 \%$ of reporting using forms. Based on the reporting of hazards, we can find out critical places that are often found irregularities so that the area is more priority in controlling hazards and risks that arise. Moreover, this application is also linear with the company's mission in environmental management because of the reduction in the use of paper to become digital. Based on the results of the study above the implementation of the I-Safe application can increase the concern of mine workers regarding work safety and the recorded database can be used as a basis for valid decision making. This is in line as one form of the implementation of Indonesian mining safety management in the face of the industrial era 4.0 regarding digitalization, safety and mining.

Keywords: application, I-Safe, database, evaluation, safety

\section{A. PENDAHULUAN}

PT. Borneo Indobara merupakan salah satu perusahaan yang bergerak di bidang pertambangan Batubara dengan lokasi operasional penambangan berada di Kabupaten Tanah Bumbu, provinsi Kalimantan Selatan. PT. Borneo Indobara adalah PKP2B dengan luas area konsesi sebesar 24.100 Ha, yang saat ini memiliki 3 Pit Aktif yaitu Pit Kusan Bawah, Pit Kusan Atas, dan Pit Girimulya.

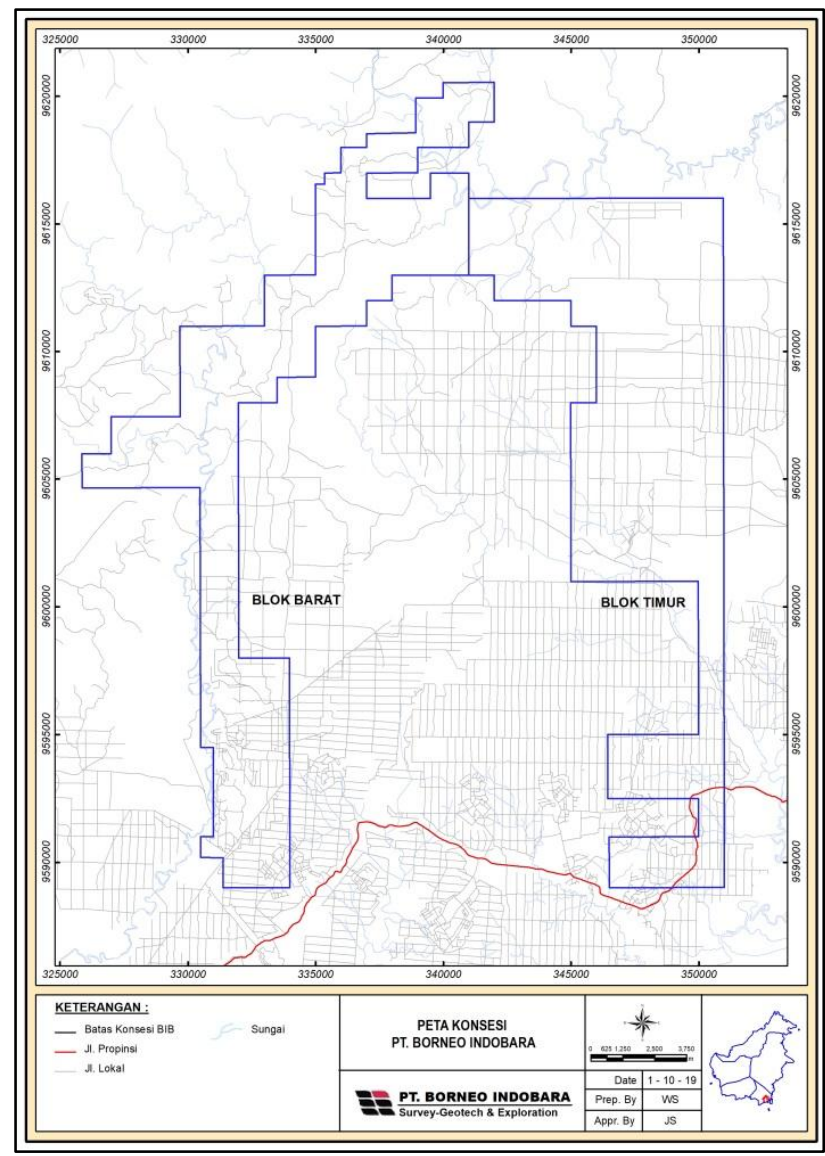

Gambar 1. Peta konsesi PT. Borneo Indobara.

Saat ini PT. Borneo Indobara sedang berupaya meningkatkan Produksi Batubara dari Tahun ke Tahun. Dalam perkembangan peningkatan produksi batubara tersebut, keselamatan kerja menjadi hal terpenting yang perlu diperhatikan agar pencapaian target produksi dapat dicapai dengan 
meminimalkan angka kecelakaan. Hal ini sejalan dengan komitmen management PT. Borneo Indobara bahwa keselamatan kerja menjadi yang Utama. Untuk itu diperlukan perbaikan berkelanjutan yang terus menerus dilaksanakan guna mendukung operasional tetap aman dan selamat dalam mencapai target produksi yang telah ditetapkan.

Pengelolaan keselamatan kerja di PT. Borneo Indobara berada di dalam lingkup Departemen OHS yang terbagi ke dalam 3 (tiga) seksi area pengelolaan keselamatan. Ketiga area tersebut mencakup area pengawasan keselamatan Pit Operation, area pengawasan keselamatan Hauling Coal, area pengawasan keselamatan Port \& Project. Dalam kesempatan yang baik ini, lingkup pembahasan yang akan disampaikan adalah pada pengelolaan keselamatan pada area Pit Operation. Aktifitas di area Pit Operation mencakup aktifitas pertambangan mulai dari pembebasan lahan (land clearing) hingga proses penimbunan lahan (dumping material).

Dibawah ini merupakan gambaran pencapaian produksi batubara PT. Borneo Indobara Tahun 2017 hingga Tahun 2018 dimana pada Gambar 2 terlihat produksi batubara mengalami peningkatan yang signifikan namun tidak diiringi dengan peningkatan performance keselamatan kerja yang baik seperti terlihat pada Gambar 3. Hal ini diperlihatkan dengan meningkatnya angka Total Incident Frequency Rate (TIFR) di area Pit Operation seiring dengan produksi batubara meningkat.

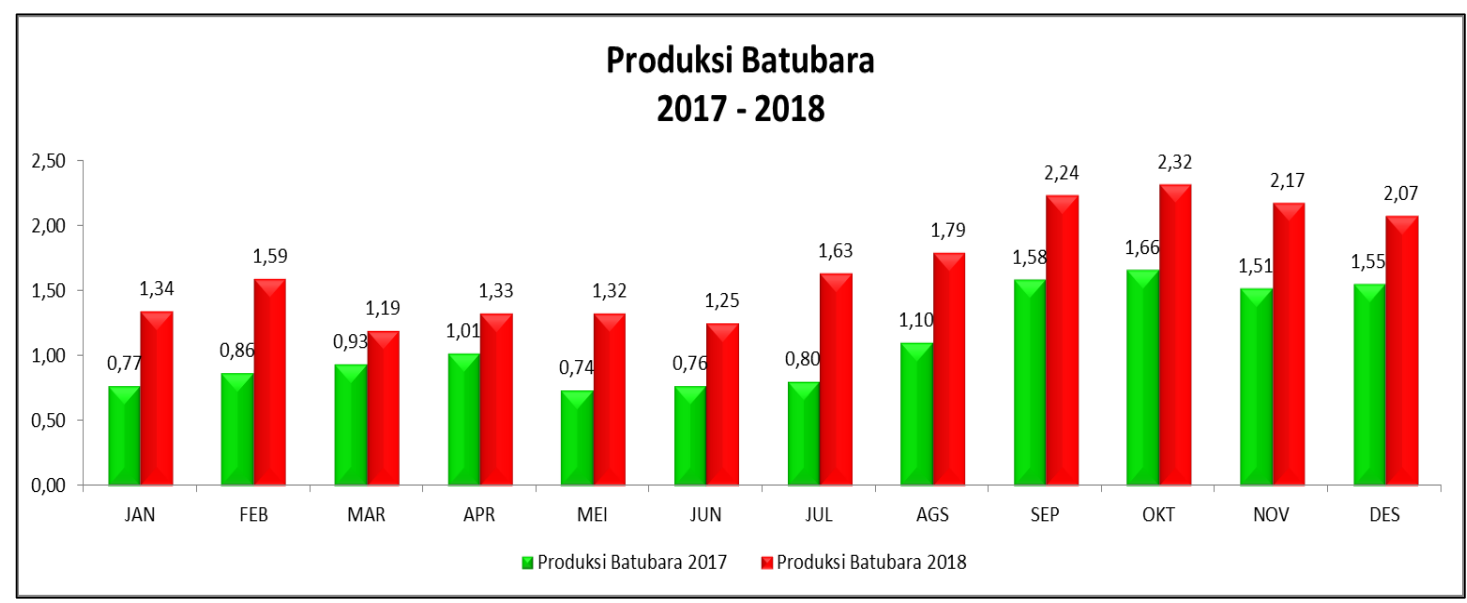

Gambar 2. Pencapaian produksi batubara tahun $2017-2018$.

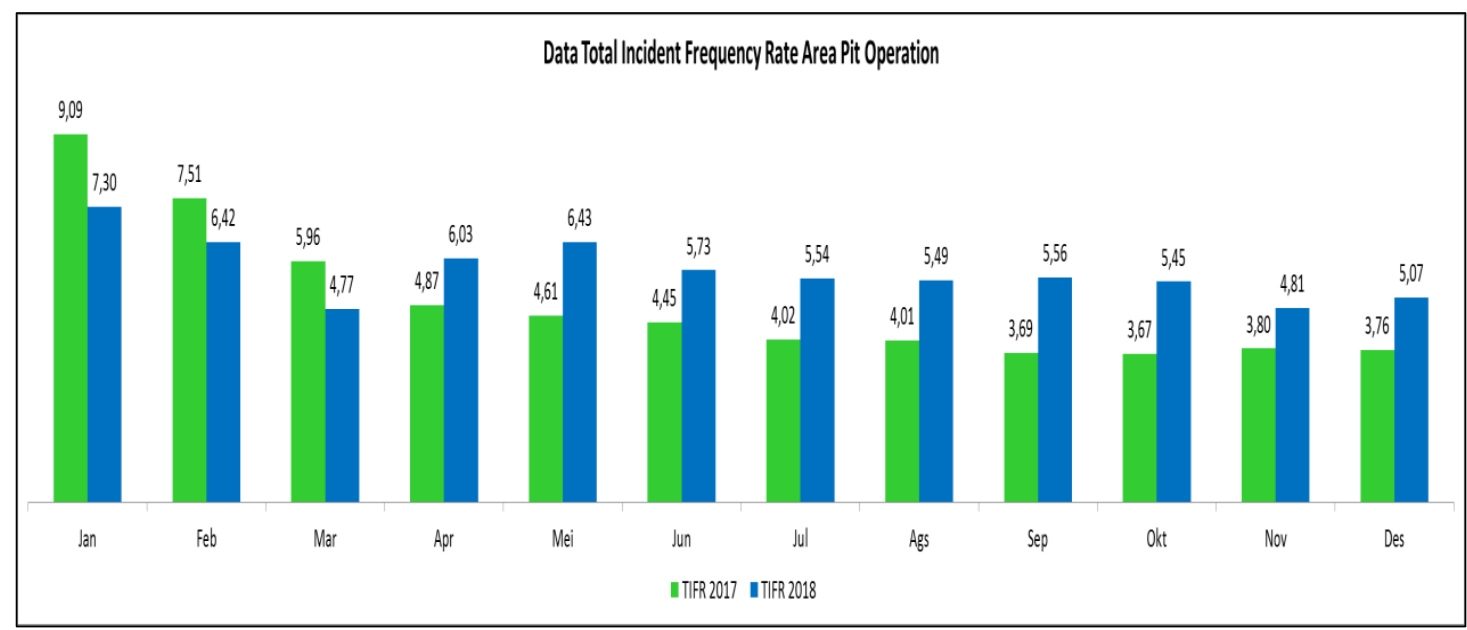

Gambar 3. Total incident frequency rate area pit operation tahun $2017-2018$.

Dengan adanya penambahan produksi batubara, hal ini diiringi dengan adanya penambahan pekerja tambang, infrastruktur, serta peralatan pertambangan. Tentunya penambahan ini meningkatkan potensi bahaya serta resiko pekerjaan di lapangan. Untuk itu pelaporan bahaya (hazard report) 
menjadi sangat penting sebagai media penyampaian indikasi upaya awal pencegahan kecelakaan (leading indicator). Pada periode Tahun 2017 hingga Tahun 2018 dimana adanya penambahan pekerja tambang (man power) yang signifikan tidak diiringi dengan adanya peningkatan pelaporan bahaya (hazard report) yang signifikan juga, melainkan Gambar 4 menunjukkan bahwa pelaporan bahaya memperlihatkan trend pelaporan bahaya di area Pit Operation masih naik turun.

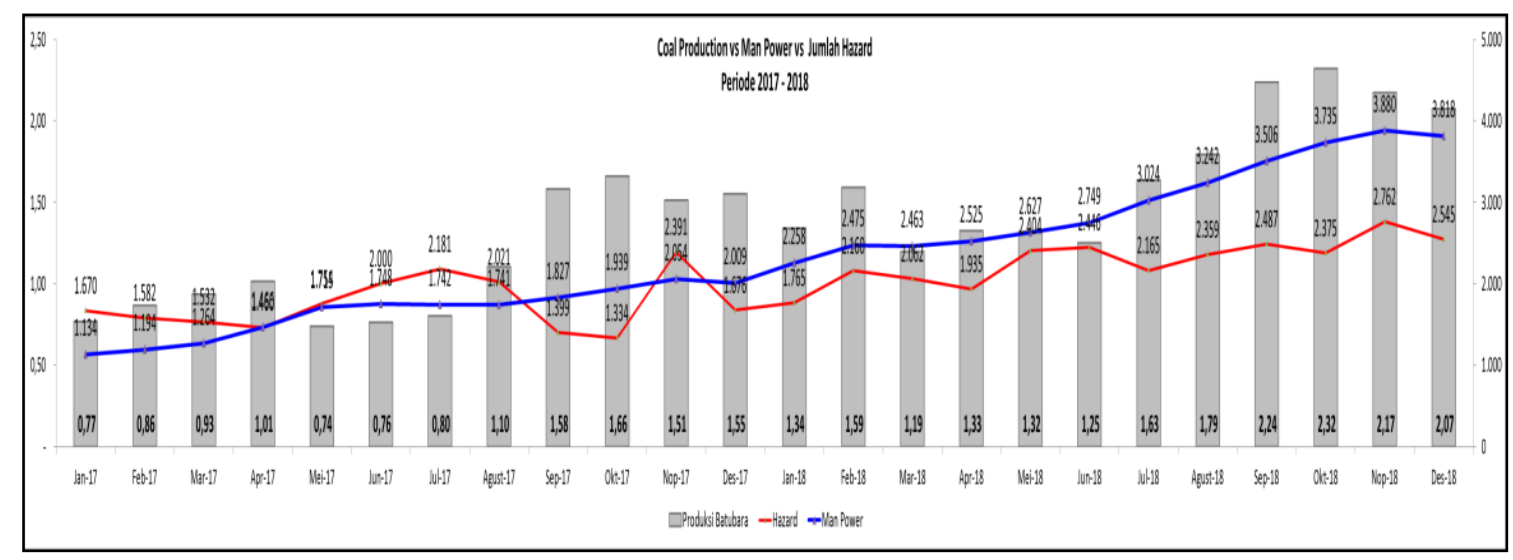

Gambar 4. Trend jumlah pekerja dan pelaporan bahaya terhadap produksi batubara.

Hal inilah yang menjadi salah satu faktor kontribusi terhadap peningkatan angka kecelakaan di area Pit Operation PT. Borneo Indobara, dimana pencegahan awal terhadap kecelakaan belum optimal dikarenakan informasi mengenai bahaya operasional belum dikelola dengan baik. Untuk itu pada Tahun 2019, dimana target produksi batubara mengalami peningkatan dari Tahun sebelumnya, sehingga sebagai upaya menjaga keselamatan operasional PT. Borneo Indobara khususnya di area Pit Operation maka langkah yang dicapai adalah dengan peningkatan pelaporan bahaya (hazard report), pelaksanaan analisa dan evaluasi data bahaya, serta penyampaian rekomendasi dari hasil analisa data bahaya untuk segera ditindaklanjuti guna mencegah terjadinya kecelakaan.

\section{B. METODOLOGI PENELITIAN}

Dalam rangka mencegah terjadinya kecelakaan dibutuhkan data leading indicator yang salah satunya berupa laporan bahaya (hazard report) yang kemudian akan dilakukan analisa oleh tim safety untuk melihat trend dan bahaya yang perlu dikelola di lapangan. Adapun metode yang akan digunakan adalah berupa metode manual (formulir) dan metode digital online yang diberi nama I-Safe. Metode manual diimplementasikan menggunakan penetapan target personal untuk seluruh pengawas operasional di kontraktor tambang area Pit Operation. Dengan adanya penetapan target diharapkan seluruh pengawas secara konsisten melaporkan kondisi atau tindakan tidak aman yang ditemukan di area yang diawasinya. Adapun target yang ditetapkan oleh PT. Borneo Indobara kepada kontraktor tambang adalah setiap pengawas kontraktor tambang di area Pit Operation diwajibkan melaporkan laporan bahaya (hazard report) sebanyak 2 laporan/shift sesuai dengan area yang menjadi tanggung jawabnya. Program ini diberi nama One Day Without Incident (ODWI). Dengan diberlakukannya target ini berhasil meningkatkan pelaporan bahaya yaitu kondisi tidak aman dan tindakan tidak aman di area Pit Operation secara signifikan di Tahun 2019 dengan rata-rata kenaikan 15\% pada pelaporan periode Januari hingga Agustus Tahun 2019.

Pelaporan dari setiap pengawas operasional diserahkan kepada tim HSE masing-masing kontraktor untuk dilakukan inputisasi data ke dalam database perusahaan. Langkah selanjutnya adalah setiap HSE kontraktor tambang setiap pagi hari pukul 08.00 wita diwajibkan melaporkan kompilasi database bahaya kepada tim Safety PT. Borneo Indobara. Setelah tim Safety PT. Borneo Indobara memperoleh data dari kontraktor tambang, kemudian tim Safety PT. Borneo Indobara melakukan verifikasi dan validasi data yang selanjutnya melakukan analisa serta evaluasi data laporan bahaya 
tersebut. Hasil dari analisa dan evaluasi tersebut disampaikan dalam bentuk Dashboard Hazard kepada seluruh departemen mining operation PT. Borneo Indobara untuk segera dilakukan perbaikan berdasarkan lokasi dan jenis temuan bahaya yang diterima.

Adapun kendala yang dialami dengan metode pelaporan manual menggunakan formulir adalah terkait dengan kecepatan penerimaan data oleh tim Safety PT. Borneo Indobara. Dimana data pelaporan bahaya diterima oleh Safety PT. Borneo Indobara pada keesokan harinya. Hal ini menimbulkan potensi kepada kecepatan respon untuk perbaikan temuan bahaya itu sendiri, dimana tim evaluasi data tidak mendapatkan gambaran umum terkait bahaya secara keseluruhan dalam waktu segera. Selain itu, kendala yang sering muncul adalah parameter analisa yang masih beragam dan belum seluruh laporan dimasukkan ke dalam database laporan bahaya.

Pada Dasarnya PT. Borneo Indobara telah mempersiapkan database yang telah tervalidasi dengan baik untuk digunakan secara serentak oleh kontraktor tambang di area Pit Operation. Hal ini untuk memberikan parameter, data, dan cakupan jenis ketidaksesuaian/temuan yang sama sehingga pada proses analisa serta evaluasi memberikan kemudahan untuk penyampaian visualisasi analisa data tersebut. Namun dalam pelaksanaannya tidak seluruhnya dapat dimasukkan ke dalam database dikarenakan banyaknya laporan yang telah diterima oleh HSE kontraktor tambang namun keterbatasan personil HSE kontraktor tambang dalam melakukan inputisasi data menjadi faktor Utama penyebab belum 100\% laporan bahaya dimasukkan dalam database.

Untuk mengatasi kendala di atas yaitu terkait dengan belum terinput $100 \%$ pelaporan bahaya dalam database, waktu penerimaan laporan bahaya oleh tim Safety PT. Borneo Indobara yang membutuhkan waktu lebih dari 1 hari dari HSE kontraktor tambang, serta masih terdapat lambatnya respon perbaikan bahaya dikarenakan temuan bahaya yang tidak selalu langsung diketahui oleh pengawas yang bertanggung jawab atas temuan tersebut, sehingga PT. Borneo Indobara menerapkan sistem pelaporan bahaya secara Online. Metode Online ini diberi nama ISafe yang merupakan hal baru diimplementasikan secara bertahap dimulai dari internal perusahaan PT. Borneo Indobara hingga kontraktor tambang yang ada, dengan tujuan untuk mempercepat pelaporan diterima oleh Safety PT. Borneo Indobara serta memastikan parameter/item jenis temuan bahaya telah seragam untuk digunakan sebagai dasar analisa yang kemudian disampaikan dalam bentuk Dashboard kepada seluruh departemen Mining Operation PT. Borneo Indobara.

\section{HASIL DAN PEMBAHASAN}

PT. Borneo Indobara seperti disampaikan pada pembahasan sebelumnya bahwa produksi batubara mengalami peningkatan dari Tahun ke Tahun. Seiring dengan peningkatan produksi tersebut, penambahan tenaga kerja, alat pertambangan pun turut meningkat. Peningkatan ini berpotensi menaikkan angka kecelakaan di operasional pertambangan PT. Borneo Indobara.

Safety PT. Borneo Indobara khususnya section OHS Pit Operation sebagai bagian dari HSE PT. Borneo Indobara berupaya memberi kontribusi positif untuk mendukung pencapaian produksi batubara dengan peningkatan performa keselamatan kerja. Salah satu indikator keberhasilan tercapainya performa keselamatan kerja adalah dengan adanya penurunan angka Total Incident Frequency Rate (TIFR) sementara angka produksi terus meningkat.

Dalam pembahasan sebelumnya bahwa pada Tahun 2017 hingga Tahun 2018 pelaporan bahaya (hazard report) masih bersifat fluktuatif (naik turun) sedangkan angka penambahan pekerja dan alat pertambangan menunjukkan trend yang cenderung meningkat (Gambar 4). Untuk itu, di awal Tahun 2019 PT. Borneo Indobara melalui program One Day Without Incident (ODWI) menetapkan setiap pengawas untuk menyampaikan minimal 2 laporan bahaya setiap shift di lokasi kerjanya. Melalui program ODWI ini terlihat bahwa program ini dapat meningkatkan kesadaran pengawas 
operasional kontraktor tambang dalam pelaporan bahaya (hazard report) seperti terlihat pada Gambar 5.

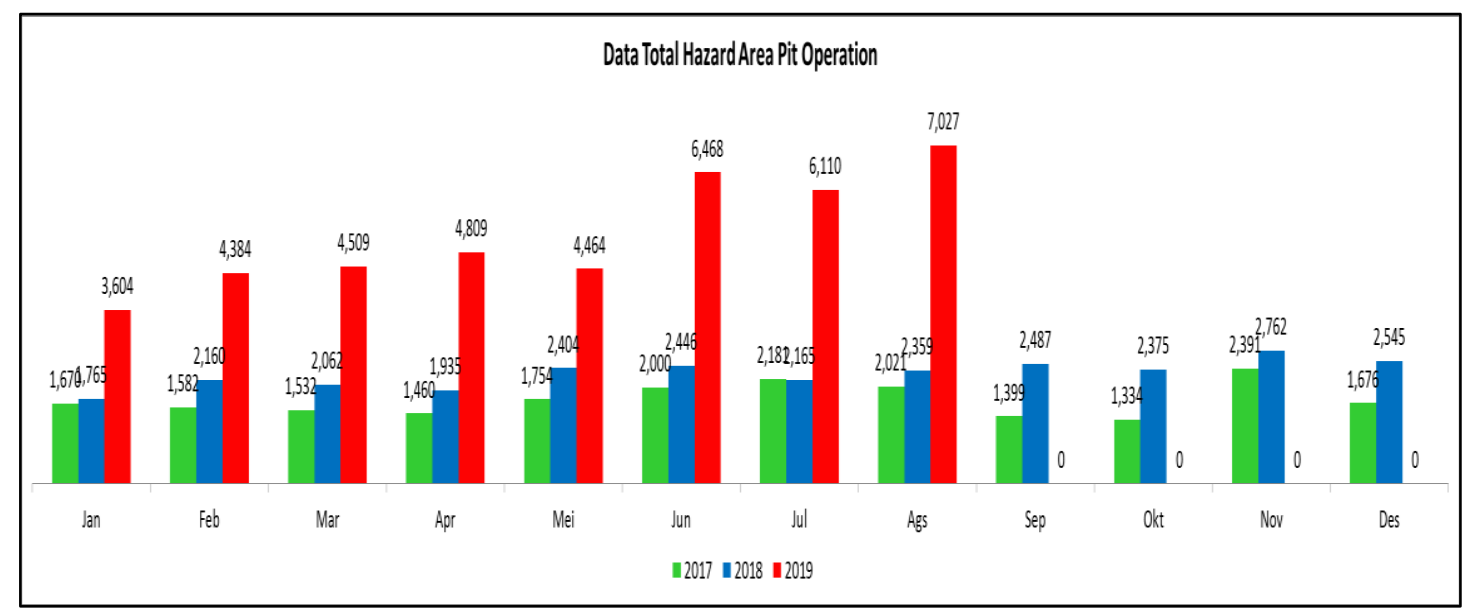

Gambar 5. Peningkatan pelaporan bahaya tahun 2019 area pit operation.

Pada grafik di atas terlihat bahwa di Tahun 2019 terdapat peningkatan sangat signifikan terkait pelaporan bahaya (hazard report) di area Pit Operation. Khususnya di Bulan Agustus 2019, pelaporan mengalami peningkatan lebih tinggi, hal ini dikarenakan adanya kontribusi pelaporan menggunakan Aplikasi I-Safe yang mulai dijalankan di pertengahan Bulan Juli 2019 di Area Pit Operation PT. Borneo Indobara. Adanya aplikasi I-Safe memberi kemudahan kepada pengawas dalam melaporkan bahaya seperti kondisi tidak aman dan tindakan tidak aman. Hal ini menjadi salah satu faktor positif dalam mendukung peningkatan pelaporan bahaya (hazard report).

Hal positif lainnya yang terlihat dari adanya peningkatan pelaporan bahaya (hazard report) adalah bahwa tim Safety PT. Borneo Indobara memperoleh data sebanyak mungkin dari pelaporan HSE kontraktor tambang guna dilakukan analisa dan evaluasi terhadap bahaya yang ada tersebut. Dari hasil analisa dan evaluasi tersebut, tim Safety PT. Borneo Indobara menyajikan hasil evaluasi menggunakan Dashboard Evaluasi (Gambar 6) sebagai media komunikasi dari tim Safety kepada seluruh departemen produksi untuk memberikan masukan terkait pengelolaan bahaya guna mencegah dan meminimalisir angka kecelakaan yang berada di area Pit Operation PT. Borneo Indobara. Dari dashboard tersebut dapat terlihat area, lokasi, jenis ketidaksesuaian, hingga sub ketidaksesuaian yang tercatat dan menjadi perhatian untuk segera dilakukan perbaikan guna meminimalisir terjadinya kecelakaan. Data dashboard tersebut tidak hanya disajikan untuk kebutuhan departemen produksi di internal PT. Borneo Indobara, melainkan data tersebut disampaikan juga kepada seluruh pengawas dan management kontraktor tambang yang berada di area Pit Operation. Dari data tersebut pun dapat dijadikan sebagai bahan kampanye keselamatan yang disesuaikan dengan isu keselamatan di masing-masing area ataupun kontraktor tambang tersebut.

Dari hal tersebut (analisa evaluasi data bahaya), dapat terlihat bahwa pelaporan bahaya yang telah dianalisa dan segera ditindaklanjuti telah berhasil menurunkan angka Total Incident Frequency Rate (TIFR) di Tahun 2019 pada area Pit Operation. Hal ini memberikan kontribusi dan performance nilai positif pada keselamatan operasional PT. Borneo Indobara, dimana produksi batubara yang meningkat setiap tahun (Gambar 7), pekerja tambang dan alat pertambangan yang terus meningkat, namun performa keselamatan kerja yaitu angka TIFR berhasil diturunkan seperti terlihat pada Gambar 8, dimana angka TIFR Area Pit Operation Tahun 2019 tidak melebihi angka TIFR dari Tahun 2018. 


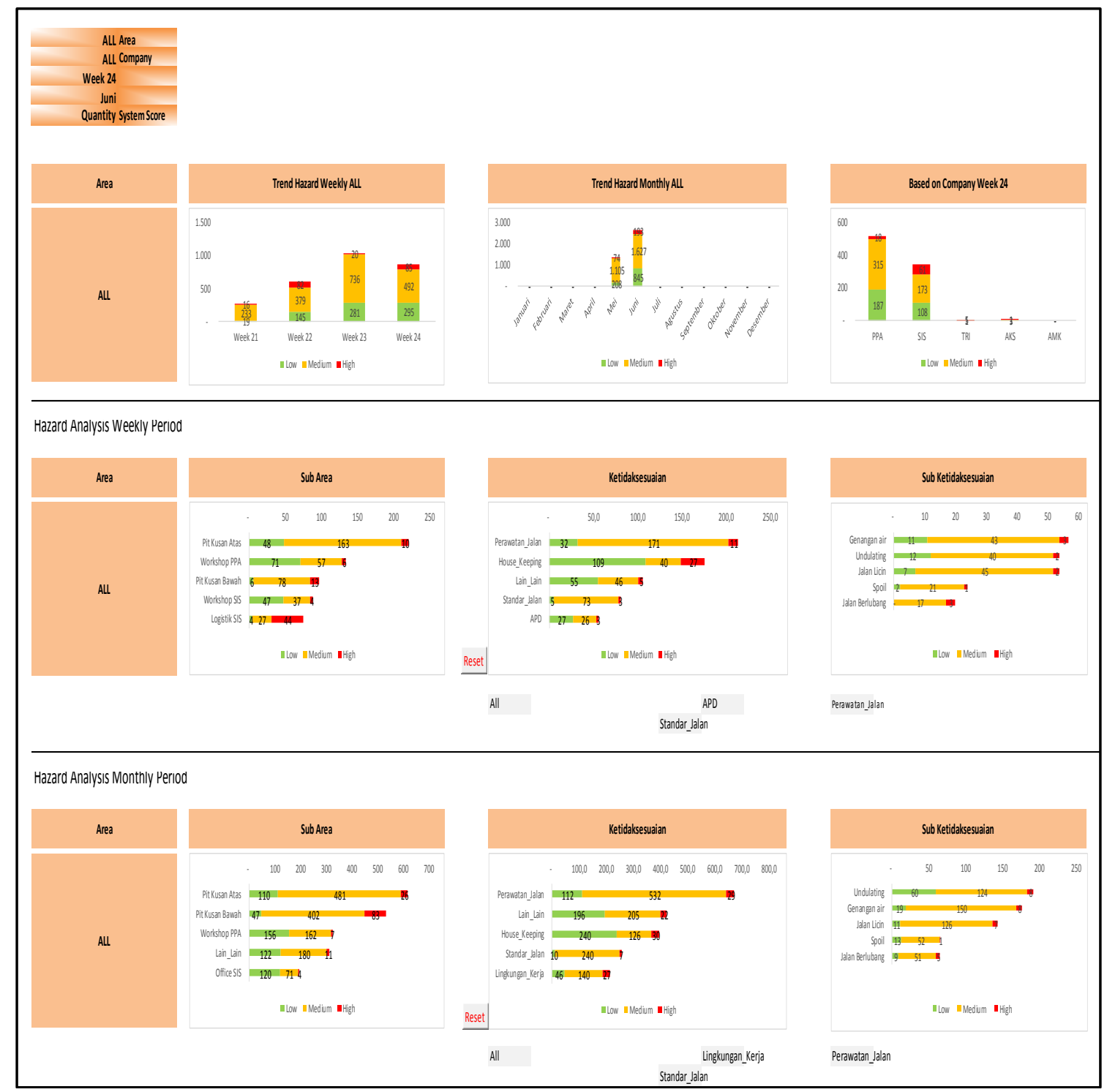

Gambar 6. Dashboard evaluasi laporan bahaya PT. Borneo Indobara.

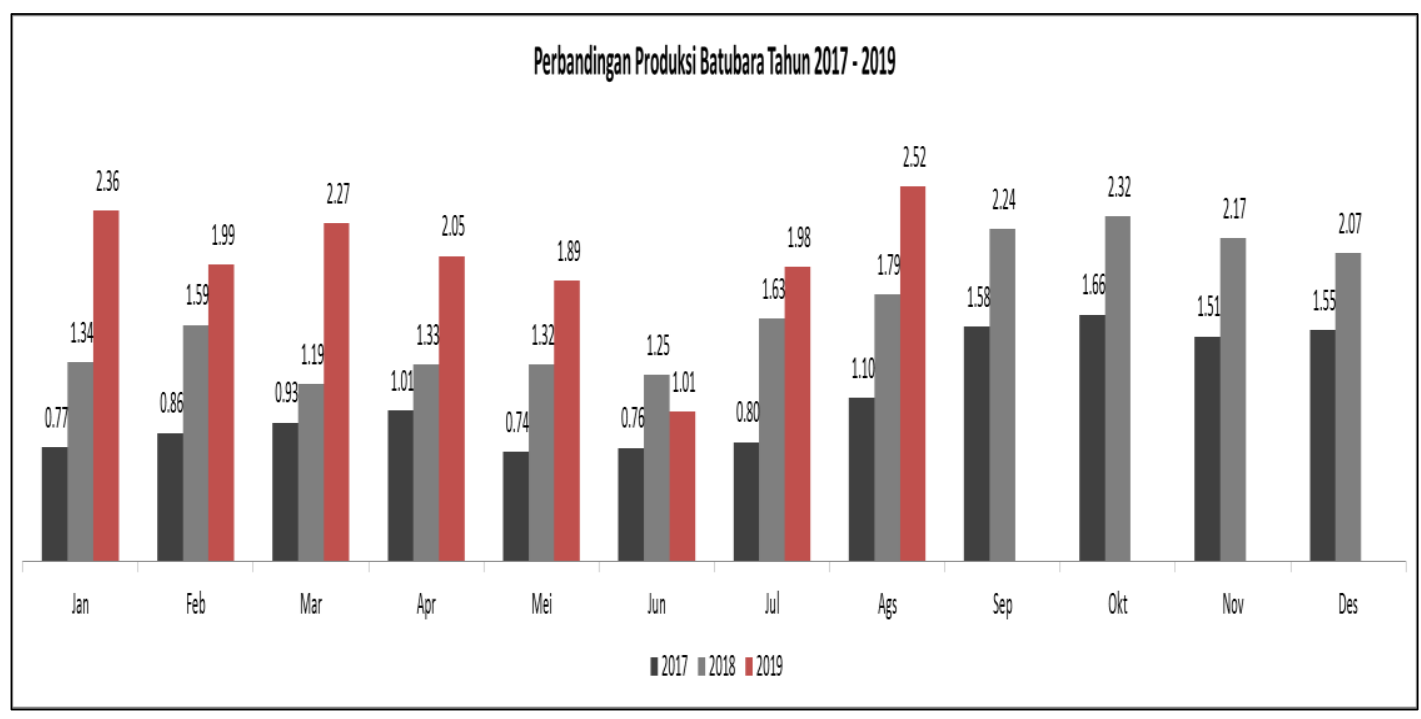

Gambar 7. Perbandingan produksi batubara PT. Borneo Indobara tahun 2017 - 2019. 


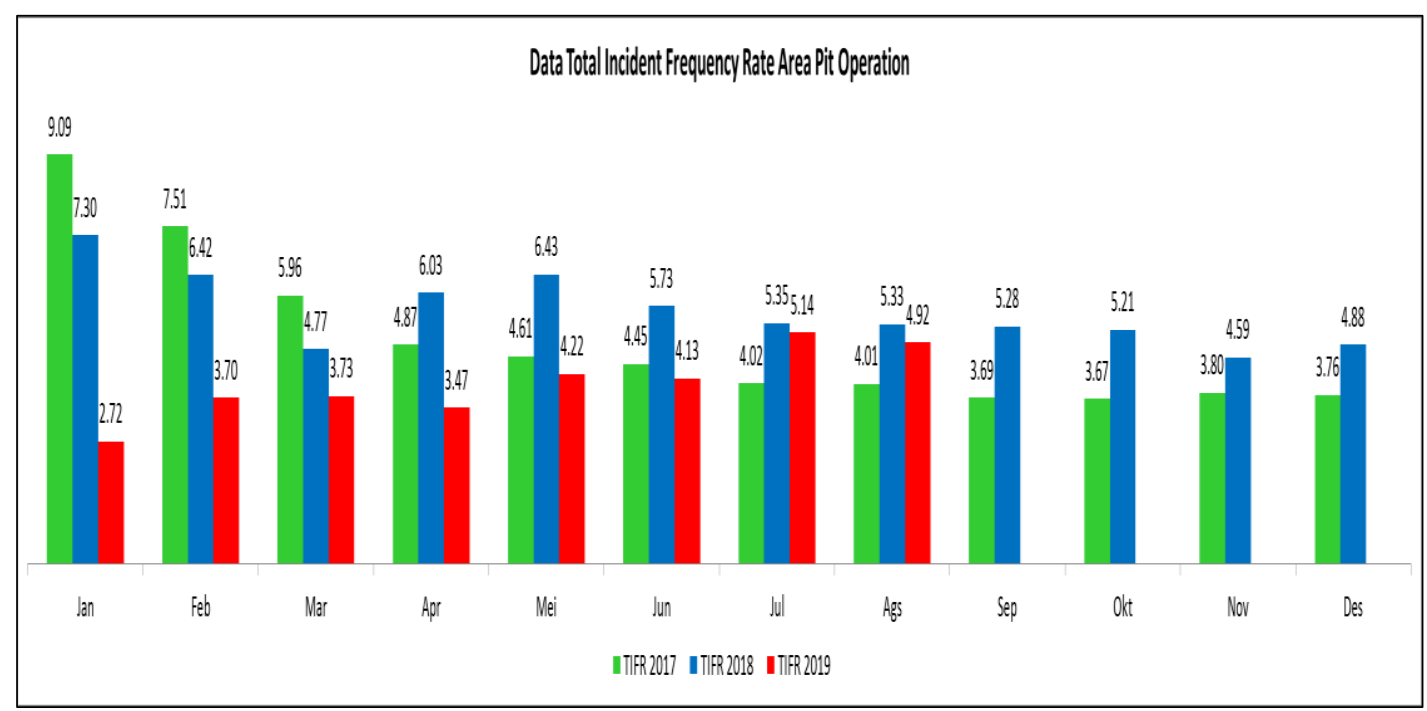

Gambar 8. Perbandingan angka TIFR area Pit Operation tahun $2017-2019$.

Aplikasi I-Safe yang diimplementasikan di pertengahan Bulan Juli dan secara penuh dijalankan di Bulan Agustus (Gambar 9), dimana dalam penggunaan aplikasi I-Safe ini tersedia beberapa hal yang dibutuhkan dalam pelaporan seperti deskripsi temuan, jenis ketidaksesuaian, jenis sub ketidaksesuaian, lokasi temuan, serta pengawas yang bertanggung jawab atas temuan tersebut yang secara otomatis muncul namanya sesuai lokasi ditemukannya bahaya. Aplikasi I-Safe ini telah memberikan dampak positif dalam kebutuhan dan perkembangan analisa serta evaluasi data laporan bahaya. Hal ini telah terlihat pada Gambar 5 dimana pada Bulan Agustus pelaporan bahaya mengalami peningkatan pelaporan yang sangat signifikan. Dengan adanya penggunaan aplikasi $\boldsymbol{I}$ Safe ini memberikan perubahan besar dalam sisi pelaporan. Dimana tim Safety PT. Borneo Indobara dapat segera mendapatkan pelaporan bahaya yang ada sehingga dapat secepatnya dilakukan analisa dan evaluasi. Pelaporan bahaya yang telah dianalisa dan dievaluasi, kemudian menggunakan media Dashboard Evaluasi disampaikan kepada penanggung jawab area untuk ditindaklanjuti sehingga harapannya adalah dengan perbaikan segera terhadap laporan bahaya, maka bahaya tersebut tidak berkembang menjadi kejadian kecelakaan. Pada akhirnya angka Total Incident Frequency Rate di PT. Borneo Indobara dan secara khusus di area Pit Operation dapat berkurang.

Dampak positif lainnya dari implementasi I-Safe terlihat pada Gambar 7 dan Gambar 8, dimana pada Gambar 7 di Bulan Agustus 2019 merupakan periode dimana produksi batubara PT. Borneo Indobara merupakan pencapaian produksi tertinggi sepanjang PT. Borneo Indobara beroperasi. Peran I-Safe terlihat dimana produksi batubara terus meningkat dan mencapai titik tertinggi di Bulan Agustus (Gambar 7) namun angka Total Incident Frequency Rate (TIFR) di Area Pit Operation pada Bulan Agustus menunjukkan angka yang lebih rendah dari Bulan Juli bahkan tidak melebihi Angka Total Incident Frequency Rate (TIFR) dari Tahun 2018. Hal ini menunjukkan bahwa hasil dengan implementasi I-Safe (Gambar 10) memberikan kontribusi dalam perbaikan segera terhadap laporan kondisi tidak aman ataupun tindakan tidak aman yang ada. 


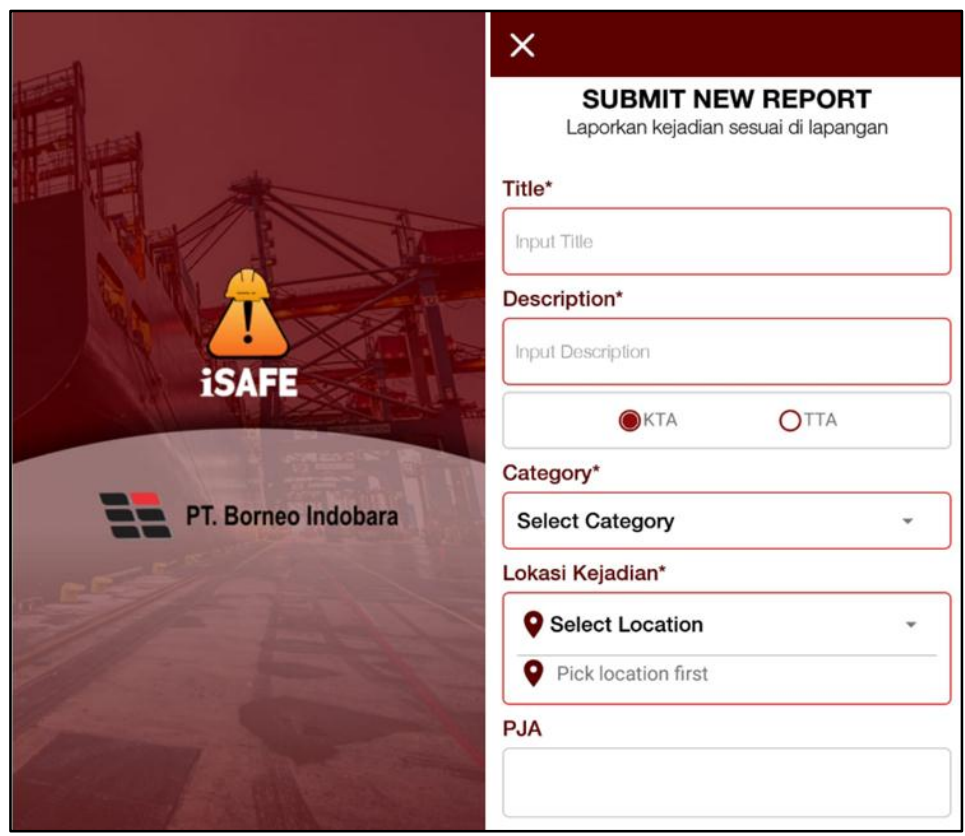

Gambar 9. Tampilan aplikasi I-Safe.

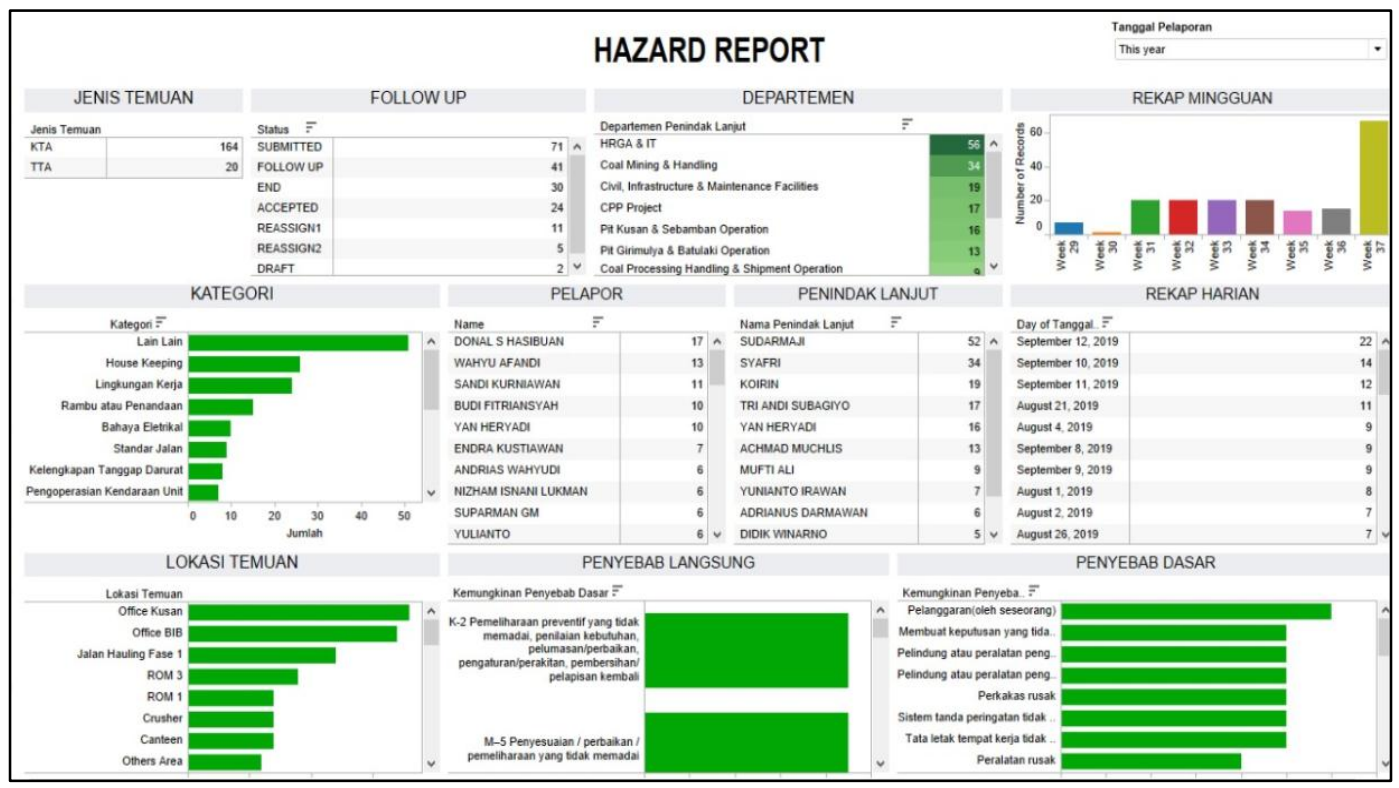

Gambar 10. Data pelaporan bahaya melalui aplikasi I-Safe.

\section{KESIMPULAN}

PT. Borneo Indobara sebagai salah satu perusahaan pertambangan batubara (PKP2B) yang saat ini sedang berkembang, senantiasa meningkatkan angka produksi batubara dari tahun ke tahun. Peningkatan produksi batubara senantiasa diiringi dengan penambahan tenaga kerja, alat pertambangan yang tentunya meningkatkan potensi bahaya dan potensi terjadinya kecelakaan di area operasional pertambangan PT. Borneo Indobara. Salah satu upaya pencegahan kecelakaan adalah dengan meningkatkan pelaporan bahaya (hazard report) oleh pengawas operasional. Pelaporan bahaya yang ada sebelum Tahun 2019 di PT. Borneo Indobara terhitung masih minim jika dibandingkan dengan jumlah penambahan produksi dan tenaga kerja yang ada. Untuk itu, di Tahun 2019 dilaksanakan Program One Day Without Incident (ODWI) untuk meningkatkan 
pelaporan bahaya dari seluruh pengawas operasional yang ada dengan menggunakan formulir pelaporan bahaya (hazard report form).

Pelaporan dengan menggunakan formulir memiliki kekurangan yang menjadi kendala dalam evaluasi data bahaya, yaitu memerlukan waktu yang lama untuk inputisasi data ke dalam database. Untuk itu, PT. Borneo Indobara menciptakan Aplikasi I-Safe untuk memberi kemudahan pada pengawas operasional untuk melaporkan bahaya yang ada. Aplikasi I-Safe yang dijalankan pada pertengahan Juli telah menunjukkan kontribusi positif dalam meningkatkan pelaporan bahaya sebesar $15 \%$ dari pelaporan manual yang dilakukan sebelumnya. Selain itu, aplikasi I-Safe pun telah berkontribusi positif dalam menurunkan angka Total Incident Frequency Rate (TIFR) di Area Pit Operation, dimana pada Periode Agustus 2019 merupakan pencapaian tertinggi produksi batubara PT. Borneo Indobara dan pada periode yang sama tersebut angka Total Incident Frequency Rate (TIFR) di Area Pit Operation mengalami penurunan dibandingkan bulan sebelumnya, bahkan tidak melampaui angka TIFR pada Tahun 2018.

Produksi batubara PT. Borneo Indobara akan terus meningkat dari waktu ke waktu. Namun dengan adanya konsistensi dari para pengawas kontraktor tambang dalam melaporkan bahaya di tempat kerjanya serta dilengkapi dengan sistem pelaporan yang bersifat online melalui aplikasi I-Safe, kami sangat yakin bahwa keselamatan operasional dapat terus ditingkatkan. Produksi batubara, jumlah pekerja tambang, jumlah alat pertambangan yang terus meningkat tidak lagi menjadi hal yang perlu dikuatirkan sebagai kontributor penyebab kecelakaan, selama seluruh pihak berperan aktif dalam melaporkan setiap kondisi tidak aman ataupun tindakan tidak aman. Tim Safety PT. Borneo Indobara pun akan selalu bersedia melakukan analisa dan evaluasi guna perbaikan segera untuk mencegah angka kecelakaan meningkat.

\section{DAFTAR PUSTAKA}

Dr. S. Ravichandran. 2012. Importance of Software System Safety with Reference to Customer Point to View, ISSN 0976 - 6375 October-December 2012, Chenai India.

Mariam Azwa Yazid dan Azrul Hazri Jantan. User Experience Design (UXD) of Mobile Application: An Implementation of a Case Study, E-ISSN: 2289-8131, Serdang, Selangor, Malaysia.

Peraturan Menteri Energi dan Sumber Daya Mineral Nomor 38 Tahun 2014, "Penerapan Sistem Manajemen Keselamatan Pertambangan Mineral dan Batubara" 